\title{
DAMPAK KARAKTERISTIK KEPRIBADIAN WIRAUSAHA TERHADAP KESUKSESAN BISNIS.
}

\author{
Salim Al Idrus \\ Fakultas Ekonomi Universitas Islam Negeri (UIN) \\ Maulana Malik Ibrahim Malang \\ J1. Gajayana 50 Malang \\ Email : salim.alaydrus@yahoo.com \\ Hp.081331227766
}

\begin{abstract}
Abstrak: The researchs aims to identify personal characteristic of entrepreneurs in suporting their business. The purpose of research is to recognize the all variables and also partial of personal characteristic entrepreneurs to their successful of business. The research has indicated that work ethos, motivation to compete, resist competency, leadership style, the capability to look at the possibility of business, managerial capability and the main power have influenced to the successful of business. Variable motivation to compete is the dominant variable for increasing the successful of businss.
\end{abstract}

Keywords: personal characteristics, the successful of business.

Secara teoritis sebagaimana yang dikembangkan di Barat (Amerika Serikat), terdapat beberapa sifat-sifat utama yang harus dimiliki bagi seseorang yang ingin meeliti karier sebagai wirausaha. Sifat-sifat itu meliputi selfconfidence, task result oriented, risk taker, leadership, originality, future oriented, proactive, achievement and commitment (Steade, Lowry and Glos, 1998). Dalam penelitian ini beberapa sifat tersebut diadopsi dan sebagian yang lain diambil dari jurnal yang ditulis oleh Littunen (2000) dalam "Entrepreneurship and the Characteristics of the Entrepreneurial Personality". Penggabungan sifat-sifat atau karakteristik tersebut didasarkan pada pertimbangan bahwa wirausaha Indonesia memiliki perbedaan perilaku dengan wirausaha di Barat sebagai akibat dari adanya perbedaan budaya, lingkungan, sistem perekonomian dan sistem pendidikan yang dikembangkan. Pilihan sifat-sifat wirausaha yang dijadikan sebagai variabel penelitian ini didasarkan dari hasil survei pendahuluan yang dilakukan pada beberapa wirausaha yang beroperasi di kota Malang. Berdasarkan pandangan tersebut diliarapkan dari penelitian ini dapat diketemukan sifat-sifat tersebut pada banyak wirausaha yang berfungsi sebagai kekuatan pendorong dalam menjalankan bisnisnya dan menuai kesuksesan. Sehingga dapat digunakan 
untuk menjeneralisasikan sifat-sifat yang harus dimiliki wirausaha untuk mencapai kesuksesan bisnisnya. Dengan kata lain, jika seorang wirausaha atau calon wirausaha memiliki sifat-sifat utama (superior talent) tersebut, maka besar kemungkinan ia akan dapat menjadi wirausaha yang berhasil.

Untuk mendapatkan informasi atau gambaran karakteristik utama yang harus dimiliki wirausaha, metode yang digunakan adalah interviu mendalam (depth interview) dan pengisian kuesioner. Kedua alat (tools) tersebut dipandang yang paling tepat untuk mendapatkan atau memperoleh informasi yang dicari sebagaimana yang banyak digunakan dalam penelitian perilaku (behavior research). Untuk memahami karakteristik kepribadian seseorang, para peneliti melakukannya dengan cara menciptakan komunikasi yang fokus dan mendalam. Di samping itu juga sering digunakan kuesioner untuk melengkapi data yang diperlukan. Kedua cara tersebut diadopsi dalam penelitian ini.

Dari hasil penelitian ini target khusus yang ingin dicapai adalah dapat disusun materi pelatihan khususnya berkenaan dengan upaya merubah karakteristik kepribadian seseorang yang dapat diterapkan (applicable) untuk kondisi di Indonesia bagi calon wirausaha ataupun para wirausaha yang belum berhasil mengembangkan bisnisnya. Untuk tujuan jangka panjang diharapkan lebih banyak lagi karakteristik perilaku yang dapat digali yang merupakan kekhasan wirausaha Indonesia yang berhasil. Diharapkan Karakteristik perilaku tersebut dapat ditularkan alat dibentuk kepada seseorang atau kelompok melalui program pelatihan yang didesain secara sistimatis. Sehingga akan banyak wirausaha-wirausaha yang menjalankan bisnisnya secara berhasil yang akan berdampak positip terhadap perkembangan perekonomian Indonesia.

Hawkins dan Turla (1986) mengartikan wirausaha (entrepreneur) adalah: "seorang yang mampu mengatur, menjalankan, menanggung risiko bagi pekerjaan yang ditempuhnya dalam dunia bisnis". Namun dalam realitasnya para wirausaha mempunyai makna lebih dari sekadar yang termaktub dalam definisi tersebut. Wirausaha adalah orang yang memiliki talenta khusus yang dikembangkannya sehingga mampu menciptakan sesuatu yang bernilai. Dia mempunyai impian dan mengubahnya menjadi sesuatu kenyataan yang hebat. 
Mereka adalah orang-orang yang sering bekerja selama 80 jam dalam seminggu. Meskipun usia dan bakat mereka berbeda-beda, tidak peduli tinggal di mana. Pada dasarnya mereka adalah pencipta kreatif yang karyanya sering dikagumi dan diminati pasar. Apapun macam produk atau jasa yang diberikan, seorang wirausaha yang berhasil selalu dapat mempersatukan antara impian dengan realitas yang dibangunnya.

Wirausaha menurut Musselman dan Jackson (1984) adalah seseorang yang menginvestasikan dan mempertaruhkan waktu, uang dan bisnis untuk memulai suatu perbisnisan dan menjadikannya berhasil. Berdasar pemahaman tersebut mengisyaratkan bahwa menjadi wirausaha tidak sekadar memulai bisnis dan menjalankan bisnis tersebut, akan tetapi memiliki tanggung jawab menjadikan bisnis tersebut berhasil dalam arti berkembang dan mengalami kemajuan. Pencapaian kesuksesan bisnis diperlukan kualitas pribadi yang mendukung untuk dapat merencanakan, menjalankan, mengembangkan dan mengatasi berbagai permasalahan bisnis maupun pribadi. Seorang wirausaha sejati memperoleh kepuasan dan imbalan dengan melayani kebutuhan orang lain.

Sampai tingkat tertentu kesuksesan sebagai seorang wirausaha bergantung kepada kesediaannya untuk bertanggungjawab atas pekerjaan sendiri. Orang harus belajar banyak tentang dirinya sendiri, jika ia bermaksud untuk mencapai tujuan dan yang sesuai dengan apa yang paling diinginkan dalam hidup ini. Kekuatan seseorang datang dari tindakan-tindakannya sendiri dan bukan dari tindakan orang lain. Meskipun risiko kegagalan itu ada, para wirausaha mengambil risiko dengan jalan menerima tanggungjawab atas tindakan mereka sendiri. Kegagalan harus diterima sebagai pengalaman belajar (Meredith, et al., 1995). Beberapa wirausaha berhasil setelah mengalami banyak kegagalan dan hasil suatu riset menunjukkan bahwa dari kegagalan demi kegagalan tersebut, akhimya ia bisa mencapai puncak kesuksesan. Oleh karena itu, belajar dari pengalaman-pengalaman masa lalu akan banyak membantu dalam mencapai hasil-hasil yang lebih positif, dan kesuksesan merupakan buah dari bisnis yang tidak mengenal lelah. Kebanyakan orang tidak menyadari luasnya bidang di mana mereka dapat menentukan tindakantindakannya. Mencapai kesempurnaan merupakan sesuatu yang ideal dalam mengejar tujuan, tetapi bukan sasaran yang realistik bagi kebanyakan wirausaha. 
Hasil yang dapat diterima adalah lebih penting daripada hasil yang sempurna. Berbisnis mencapai hasil secara sempurna demi satu tujuan dalam jangka waktu yang terlalu lama hanya akan menghambat perkembangan dan pertumbuhan pribadi anda.

Meskipun tidak ada persyaratan latar belakang pendidikan khusus yang harus dimiliki bagi seseorang untuk memulai bisnis sendiri atau menjadi wirausaha, namun terdapat beberapa persyaratan lain yang harus ada yang menyangkut ciri-ciri dan sifat-sifat sebagai wirausaha supaya mereka mampu menjalankan usalianya secara baik dan berhasil. Menurut Musselmar, dan Jackson (1984) dalam bukunya Introduction to Business mengemukakan beberapa ciri-ciri perilaku wirausaha, yaitu: (1) Keinginan kuat untuk berdiri sendiri; (2) Kemampuan untuk mengambil risiko-, (3) Kemampuan untuk belajar dari pengalaman; (4) Memotivasi diri sendiri; (5) Semangat untuk bersaing; (6) Orientasi pada kerja keras; (7) Percaya pada diri sendiri; (8) Dorongan untuk berprestasi; (9) Tingkat energi yang tinggi; (10) Tegas; dan (11) Yakin pada kemampuan diri sendiri.

Hawkin dan Turla (1986) dalam bukunya Test Your Entrepreneurial IQ, melakukan studi untuk mengetahui karakteristik wirausaha yang menjadikan mereka berhasil. Karakteristik wirausaha yang dikemukakan tersebut meliputi: (1) Kebebasan; (2) Disiplin; (3) Kreativitas; (4) Dorongan dan keinginan; dan (5) Percaya diri. Littunen (2000) mengemukakan pendapat Chell, Haworth, dan Bearley bahwa sifat-sifat itu lazim dinamakan sebagai interpersonal compentence yakni kemampuan untuk: (1) Mengendalikan diri (self-control); (2) Bekerja keras (hardwork); (3) Kemauan untuk terus belajar (learning process); (4) Kemampuan untuk bergaul (good relation); (5) Kemampuan berkomunikasi (master of communication).

Hasil studi Low dan Macmillan (1998) menunjukkan bahwa terdapat pengaruh orang tua sebagai wirausaha kepada anak-anak mereka. Para mahasiswa yang kuliah pada jurusan bisnis adalah memang kebanyakan berasal dari anakanak para pengbisnis. Semenjak kecil mereka sudah diarahkan untuk menjadi wirausaha dan dikondisikan dengan lingkungan yang memungkinkannya untuk menjadi wirausaha. Minat mereka menjadi wirausaha semakin kuat didorong oleh 
pergaulannya dengan orang-orang yang biasa berbicara dan membahas masalahmasalah yang berkaitan dengan kewirausahaan dan juga gaya hidup yang mereka tampilkan. Dengan demikian penelitian itu menunjukkan bahwa untuk melahirkan seorang calon wirausaha diperlukan upaya yang terarah secara jelas. Di mana perilaku, watak, pola berpikir dan cara kerja atau secara umum dikatakan sebagai personal competence sudah harus diprogram semenjak masa kanak-kanak sebelum memasuki bangku kuliah. Oleh karena itu, jiwa yang demikian akan semakin subur ketika mengikuti pendidikan di Perguruan Tinggi. Kesimpulan dari penelitian ini adalah: (1)Wirausaha dapat diciptakan; (2) upaya itu dapat dilakukan ketika orang yang dipersiapkan masili belum dewasa, (3) lingkungan sangat berpengaruh terhadap perkembangan jiwa calon wirausaha; (4) harus terdapat suatu kondisi yang memungkinkan calon wirausaha terkesan untuk menjadi seorang wirausaha; dan (5) adanya sistem pendidikan yang mampu memberikan stimulasi agar orang suka menjadi wirausaha.

Chell, et al. (1991) dalam studinya membandingkan wirausaha dan bukan wirausaha. Seorang wirausaha memiliki karakteristik motivasi diri, pengendalian diri, pengambilan risiko dan kreatif. Sikap, keterampilan hubungan antar pribadi, dan proses pengamatan sosial dipelajari dari seseorang dalam proses menjadi wirausaha. Wirausaha tidak hanya dilahirkan, tetapi mereka bisa dibentuk. Suatu penelitian ke dalam psikologi menghasilkan temuan baru yang mempunyai dua implikasi menarik: (1) Keyakinan seseorang tentang potensi wirausaha dapat diubah; dan (2) pendidikan, pelatihan, dan konsultasi bisnis mempunyai peran penting mendukung sukses seseorang untuk berwirausaha Chell, et.al. (1991). Apa yang dikemukakan oleh Chell, et al. (199 1) tersebut memberikan pandangan yang berbeda, di mana potensi seseorang dapat diubah dari seseorang yang kurang memiliki kemampuan berwirausaha untuk menjadi seorang wirausaha. Pembentukan karakteristik wirausaha tersebut dilakukan melalui proses pendidikan, pelatihan dan konsultasi.

Dalam beberapa studi kewirausahaan yang dilakukan oleh Littunen (2000) menyatakan terdapat dua pemikiran dalam membentuk wirausaha yaitu: model yang didasarkan pada sifat (trait model), dan pemikiran kontijensi (contingency thinking). Dalam trait model, pertanyaan yang muncul adalah mengapa orang- 
orang tertentu berani memulai bisnis dan mereka sukses sebagai wirausahawan. Dalam studi tersebut, kesuksesan wirausahawan tidak dilihat dalam konteks situasi yang tedadi (dihadapi). Berdasarkan model yang didasarkan pada pemikiran kontijensi, karakteristik yang dibutuhkan oleh wirausaha adalah kemajuan bersama lingkungan bisnis serta perpaduan antara individu dan lingkungannya (Gilad and Levine, 1986). Dalam hal ini pengalaman dan perubahan dalam individu memainkan peranan yang sangat penting. Sehingga menjadi wirausaha dapat merubah kehidupan seseorang yang sudah barang tentu berpengaruh pada karakteristik personal Rotter, 1975, 1990. Littunen (2000) mengemukakan teori yang umum wirausaha Mc Clelland yaitu teori kebutuhan untuk berprestasi, dan Rotter yaitu teori locus of control. Seseorang yang memiliki kebutuhan untuk berprestasi yang kuat adalah mereka yang mampu mengatasi masalah mereka, menentukan target, dan berbisnis untuk mencapai target dengan bisnis sendiri. Locus of control seseorang dapat dilihat sebagai suatu yang internal ataupun eksternal. Harapan dapat mengendalikan diri sendiri dalam hidupnya (internal), di mana tindakan seseorang akan sangat bergantung pada perilaku dan sikap yang dibawa sejak lahir. Harapan pengendalian eksternal merupakan sikap yang memfokuskan pada tindakan orang lain, takdir, keberuntungan dan kesempatan.

Kekuatan usaba baru seringkali dikembangkan sebagai bagian dari strategi hidup wirausaha. Menurut Mc Clelland (1965) hal tersebut dapat dilihat dari gambaran karakteristik yang dibutuhkan dalam berwirausaha. Risiko ekonomis, kekuatan untuk memutuskan komitmen ekonomis, dan kenyataan bahwa pendapatan personal sangat bergantung pada keuntungan bisnisnya, merupakan faktor yang menuntut karakteristik seseorang untuk berprestasi atau berwirausaha. Penelitian Basuki (2000) mengidentifikasi faktor-faktor yang menentukan minat mahasiswa Fakultas Ekonomi Universitas Brawijaya menjadi wirausaha. Studi tersebut menemukan bahwa setidak-tidaknya terdapat tiga faktor yang paling signifikan menentukan minat mahasiswa untuk menjadi wirausaha setelah menyelesaikan studinya yaitu: (1) lingkungan dimana mereka tinggal; (2) profesi orang tua atau salah satu keluarga sebagai seorang wirausaha yang cukup berhasil atau berhasil; (3) pengaruh teman. Dari temuan penelitian tersebut tampaknya 
tidak terdapat pengaruh yang cukup signifikan adanya pemberian mata kuliah kewirausahaan untuk mendorong minat mahasiswa meniadi wirausaha. Penelitian ini tidak bertujuan untuk menemukan jawaban mengapa mata kuliah kewirausahaan tidak mampu menstimulasi minat mahasiswa menjadi wirausaha. Kehadiran wirausaha terbukti mampu mendukung berkembangnya perekonomian suatu negara. Di banyak negara maju wirausaha memiliki peran penting terhadap pemenuhan kebutuhan masyarakat dan terlebih lagi bagi perkembangan perekonomian (Lambing dan Kuehi, 2003). Para wirausaha umumnya berangkat dari bisnis yang kecil (small enterprise) dengan ketekunan dan semangat juang (striving) yang tinggi. Hasilnya tidak sedikit di antara mereka yang bisnisnya menjadi berkembang bahkan bertambah besar. Secara umum, hampir semua wirausaha yang berhasil memiliki serangkaian karakteristik yang membedakan mereka dari pengbisnis pada umumnya, contohnya keberanian mengambil risiko, keterampilan berkomunikasi, komitmen dan kepedulian untuk membina hubungan yang semakin baik dengan pelanggan, bahkan sering kali hubungan dengan pelanggan dilakukan secara pribadi. Wirausaha yang berhasil juga memiliki keinginan yang kuat untuk menjadi majikan bagi diri sendiri. Hampir dari semua wirausaha yang sukses menunjukkan suatu kebutuhan yang kuat akan kebebasan pribadi dan kesempatan untuk berkembang dan untuk suatu ekspresi kreatif yang seringkali muncul seiring dengan pengoperasian bisnisnya. Karakteristik lain yang menonjol adalah berkenaan dengan fleksibilitas dan kecerdikan dalam bereaksi terhadap perubahan di pasar atau melihat peluang yang dapat dimanfaatkan, keberanian mengambil risiko, inovatif, keterampilan pemasaran dan kemampuan untuk bekerja sama (Casson, 1982).

David Birch dari Massachusets Institute of Technology menyatakan bahwa bisnis-bisnis kecil menciptakan delapan dari setiap sepuluh pekerjaan baru di Amerika Serikat. Pernyataan Birch mengakibatkan rasa ingin tahu yang cukup besar dikalangan perumus kebijakan (policy makers) dalam membina bisnis kecil sebagai suatu kebijakan publik (Lambing dan Kuehl, 2003). Pandangan Birch tersebut penting dijadikan sebagai acuan untuk mengembangkan bisnis kecil di Indonesia, berkenaan dengan efek pengganda (multiplier effects) sebagai akibat tumbuhnya bisnis-bisnis kecil. Namun kiranya penting dipahami bahwa 
mendorong tumbuhnya bisnis kecil hanya dengan serangkaian kebijakan makro masih perlu dipertanyakan efektivitasnya. Sebab tampaknya sudah menjadi kecenderungan umum dikalangan pelaku bisnis khususnya dan. masyarakat pada umumnya terjangkit penyakit latah (irrational immitative behavior), yakni meniru-niru sesuatu yang sedang menjadi gejala umum (trend), tanpa banyak mempertimbangkan kemampuan diri. Oleh karena itu, pandangan yang realistis dan dipandang cukup efektif adalah suatu peniruan ataupun adopsi pemikiran seharusnya dimulai dari esensi yang mendasari kesuksesan dari konsep-konsep yang dikembangkan tersebut. Intinya adalah bagaimana memahami kesuksesan bisnis kecil dipandang dari perspektif karakteristik pemiliknya (owners' characteristics). Berangkat dari pandangan tersebut langkah selanjutnya adalah menyusun suatu konsep pelatihan yang dapat membentuk tumbuhnya karakteristik wirausaha yang berhasil. Dengan demikian implementasi suatu konsep pemikiran berkenaan dengan kesuksesan wirausaha besar kemunakinannya akan lebih efektif.

Penelitian ini merupakan tahap awal dari suatu pemikiran untuk mengidentifikasi karakteristik perilaku wirausaha yang sukses yang dapat digunakan sebagai dasar pemahaman bahwa untuk menjadi atau berkarier sebagai wirausaha dituntut memiliki karakteristik perilaku tertentu yang kemungkinannya dapat dibentuk. Pemikiran ini menggunakan asumsi sebagaimana yang dinyatakan Gartner (1985) bahwa kebanyakan wirausaha membangun bisnisnya bukan secara kebetulan, tetapi direncanakan secara seksama. Mereka memulai bisnisnya didasarkan pada kebutuhan lingkungan dan hubungannya dengan orang lain. Atas dasar pandangan tersebut studi ini dilakukan guna menjelaskan karakteristik perilaku tertentu yang seharusnya dimiliki atau dibentuk kepada orang-orang yang ingin memulai kariernya sebagai wirausaha atau mereka yang sudah menjadi wirausaha namun belum berhasil melalui suatu program pelatlhan yang didesain secara sistematis.

Berdasar pada pandangan dari beberapa pakar kewirausahaan dan hasil penelitian yang terdahulu, maka kerangka konseptual dari penelitian ini dapat dilihat pada Gambar berikut : 


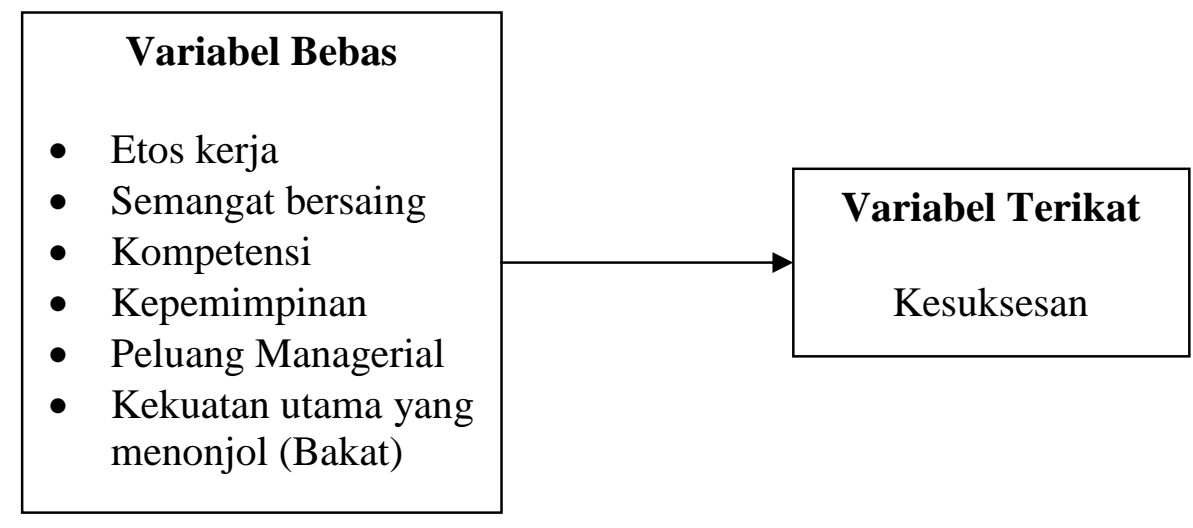

Hipotesis yang diajukan dalam penelitian ini adalah sebagai berikut: (1) diduga terdapat pengaruh yang signifikan dari variabel karakteristik kepribadian wirausaha secara simultan terhadap kesuksesan bisnis; dan (2) diduga terdapat pengaruh yang signifikan dari variabel karakteristik kepribadian wirausaha secara parsial terhadap kesuksesan bisnis.

\section{METODE}

Penelitian ini bertujuan untuk menganalisis variabel-variabel karakieristik kepribadian wirausaha yang sukses. Fokus penelitian ini bersifat penjelasan (explanation) yaitu penelitian yang bertujuan menjelaskan fenomena-fenomena yang terjadi berdasarkan pengetahuan yang sudah ada sebelumnya atau disebut verifikatif (Babble, 1992). Penjelasan yang dimaksudkan adalah mengetahui variabel-variabel yang mempengaruhi kesuksesan wirausaha dalam mengoperasikan bisnisnya, artinya penelitian ini mencari dan menjelaskan hubungan kausal antar variabel melalui pengujian hipotesis (Singarimbun, 1995). Pengujian hipotesis dibangun melalui kerangka kerja teoritis (theoritical frame work) berdasarkan penelitian sebelumnya. Pengujian variabel digunakan uji statistik parametrik, yang menggunakan alat analisis regresi berganda.

Subjek penelitian adalah karakteristik kepribadian wirausaha yang berhasil. Sedangkan objek penelitiannya adalah bisnis kecil dan menengah di bidang jasa dan proses produksi yang sudah beroperasi di wilayah Kota Malang minimal selama tiga tahun. Data dan informasi penelitian diperoleh dari beberapa 
sumber. Untuk data sekunder diperoleh dari literatur, majalah, dan jurnal. Data primer diperoleh dari responden yang merupakan sampel dalam penelitian ini. Teknik pengumpulan data menggunakan wawancara mendalam (dept-interview) dan penyebaran daftar pertanyaan (questionnaire).

Pemilihan sampel dalam penelitian ini menggunakan metode purposive sampling yakni ditetapkan oleh peneliti. Jumlah populasi bisnis kecil dan menengah yang telah membuka bisnis lebih dari tiga tahun di Kota Malang tidak dapat diketahui secara pasti mengingat tidak diperoleh data yang cukup akurat dan terpublikasikan. Untuk itu, pengambilan sampelnya dapat menggunakan metode yang dikemukakan oleh Hair, et al. (1992). Jumlah sampel penelitian yang populasinya tidak diketahui adalah 5-7 kali jumlah parameter atau 5-10 kali jumlah parameter di dalam model. Dalam penelitian ini jumlah parameter yang dijadikan sebagai variabel sebanyak 7 parameter. Jumlah sampel diambil yang paling besar yaitu 10, dengan demikian sampelnya adalah 70. Dengan tujuan supaya dapat memenuhi persyaratan pengambilan sampel, maka sampelnya ditambah 20, sehingga keseluruhan sampelnya adalah 90 responden. Jumlah daftar pertanyaan yang terkumpul setelah disebarkan kepada 90 responden adalah sejumlah 76 daftar pertanyaan.

Dalam penelitian ini uji validitas dilakukan dengan mengkorelasikan skor setiap item dengan total skor. Teknik korelasi yang digunakan adalah Pearson Product Moment, di mana instrumen dikatakan valid apabila nilai koefisien korelasinya $(r)>r$ - tabel (Santoso, 2001). Suatu angket dikatakan reliabel (andal) jika jawaban seseorang terhadap pertanyaan adalah konsisten atau stabil dari waktu ke waktu. Pengukuran yang digunakan dalam menentukan reliabilitas angket dalam penelitian ini adalah menggunakan teknik one shot atau diukur sekali saja. Dalam penelitian ini uji reliabilitas digunakan Tehnik Alpha Cronbach, di mana suatu instrumen dapat dikatakan reliabel apabila memiliki koefisien keandalan $(\alpha) \geq 0,6$ (Arikunto 1992).

Model analisis yang digunakan dalam penelitian ini adalah regresi berganda untuk mengetahui pengaruh variabel independen terhadap variabel dependen. Digunakannya model analisis regresi berganda karena terdapat hubungan antara variabel independen dan variabel dependen yang bersifat kausal 
(Davis dan Cosenza, 1993). Di samping itu analisis regresi berganda juga dapat digunakan untuk mengetahui bagaimana variabel dependen dapat diprediksikan melalui variabel independen atau prediktor. Salah satu cara untuk mendeteksi ada tidaknya gejala multicolinearity bias dilihat dari Variance Inflation Factor (VEF) dari masing-masing variabel bebas terhadap variabel terikat (Gujarati, 1995). Apabila nilai VIF tidak melebihi 10 maka mengindikasikan bahwa dalam model tidak terdapat multicollinearitas. Gejala Autokorelasi timbul sebagai akibat adanya korelasi antara anggota serangkaian observasi yang diurutkan menurut waktu (seperti dalam data deretan waktu) atau ruang (seperti data dalam cross sectional).

Untuk mengetahui ada tidaknya gejala autoregresi dalam model analisis regresi yang digunakan, maka cara yang digunakan dengan melakukan pengujian serial korelasi dengan menggunakan metode Durbin Watson. Kriteria untuk mendeteksi autokorelasi menurut Santoso (2001) adalah sebagai berikut:

- Angka D - W di bawah - 2 berarti ada autokorelasi negatif.

- Angka D - W di bawah - 2 sampai + 2, berarti tidak ada autokorelasi.

- Angka D - W di bawah +2 berarti ada autokorelasi positif.

Heteroskerjasitas merupakan suatu keadaan di mana gangguan uji (galat dari setiap variabel bebas) semuanya mempunyai variance yang tidak sama. Gejala ini mungkin timbul akibat pengamatan data berupa cross section. Cara untuk mendeteksi gejala ini antara lain dengan menggunakan uji rank korelasi (rs) dari Spearman yang diformulasikan sebagai berikut (Gujarati, 1995):

$$
\mathrm{rs}=1-5 \frac{\left[\sum d i^{2}\right]}{n\left(n^{2}-1\right)}
$$

Di mana:

$\mathrm{d}=$ Selisih rank (ei) dengan rank $x i$

$\mathrm{n}=$ Jumlah pengamatan

Gejala ini dapat diketahui dengan membandingkan $t_{\text {hitung }}$ dan $t_{\text {tabel }}$ di mana $t_{\text {hitung }}$ dicari dengan rumus berikut:

$$
\mathrm{t}=\frac{r s \sqrt{n-2}}{\sqrt{1-r s^{2}}}
$$


Apabila hasil perbandingan $\mathrm{t}_{\text {hitung }}$ dan $\mathrm{t}_{\text {tabel }}(\mathrm{df}=\mathrm{n}-2)$ menunjukkan lebih besar atau lebih kecil minus berarti Ho ditolak dan Ha diterima. Uji normalitas dimaksudkan untuk mengetahui apakah dalam model regresi, variabel dependent, variabel independent atau keduanya mempunyai distribusi normal ataukah tidak. Model regresi yang baik adalah distribusi data normal atau mendekati normal (Santoso, 2001). Melihat normalitas data dapat diketahui dari penyebaran data, pada sumbu diagonal dari grafik Normal P-P Plot dari SPSS 10,5. Uji normalitas dilihat dari penyebaran data disekitar garis diagonal dan mengikuti arah garis diagonal, maka model regresi memenuhi sumsi Normalitas.

\section{HASIL}

Pengujian pertama terhadap reliabilitas dan validitas butir-butir pertanyaan perolehan angka masing-masing butir pertanyaan dilihat dari corrected item total correlation, terdapat perolelian angka negatif dan di bawah $\mathrm{r}_{\text {tabel }}$ sebesar 0,1448 yaitu butir pertanyaan X1.1, X1.2, X1.3, X2. 1, X3.2, X3.3, X4.2, X4.3, X5.3, X5.4, X6.2, X6-3, X6.4. Perolehan reliabilitasnya yaitu $\alpha$ sebesar 0,5719. Hasil ini menunjukkan bahwa butir-butir pertanyaan tersebut kurang reliabel karena perolehan angka $\alpha$ kurang dari 0,6.

Pengujian kedua dilakukan dengan mengeliminasi butir-butir pertanyaan yang tidak memenuhi persyaratan tersebut. Perolehan $\alpha$ pada penaujian kedua sebesar 0,7416 meningkat dibandingkan dengan pengujian pertama. Hasil ini menunjukkan bahwa butir-butir pertanyaan tersebut lebih besar dari 0,6, artinya butir-butir pertanyaan tersebut reliabel. Perolehan angka corrected item total correlation pada butir-butir pertanyaan, masih terdapat beberapa butir pertanyaan yang perolehan angkanya di bawah $r_{\text {tabel }}$, sebesar 0,1448 yaitu untuk butir-butir pertanyaan X4.1, X6.3, artinya butir-butir pertanyaan tersebut tidak valid.

Pengujian ketiga dilakukan dengan mengeliminasi butir-butir pertanyaan X4.1 dan X6.3. Perolehan $\alpha$ sebesar 0,7834, hasil ini menunjukkan bahwa butirbutir pertanyaan reliabel. Perolehan angka corrected item total correlation untuk butir-butir pertanyaan tersebut tidak terdapat perolehan angka negatif dan lebih besar dari $r_{\text {tabel, }}$, hasil ini menunjukkan bahwa butir-butir pertanyaan tersebut valid. Setelah dilakukan pengujian validitas dan reliabilitas maka pada tahap selanjutnya 
dilakukan analisis regresi berganda, yaitu untuk mengetahui pengaruh variabel etos kerja, semangat untuk bersaing, kompetensi bisnis, gaya kepemimpinan, kemampuan melihat peluang bisnis, kemampuan manajerial, kekuatan utama yang mononjol terhadap variabel kesuksesan bisnis. Hasil analisis ini disajikan dalam bentuk persamaan sebagai berikut:

$Y=0,664-0,032 X_{1}+0,338 X_{2}-0,184 X_{3}-0,022 X_{4}+0,299 X_{5}-0,066 X_{6}+$ $0,168 \mathrm{X}_{7}$

Hasil tersebut kemudian dilakukan uji asumsi klask hal im dimaksudkan agar hasil tersebut dapat digunakan untuk pengambilan keputusan atau memenuhi persyaratan digunakan dalam mengambil suatu kebijakan. Pengujian terjadinya multikolinearitas dilakukan dengan melihat nilai variance inflation factor (VIF) dari masing-masing variabel bebas terhadap variabel terikat. Hasil Uji Multikolinearitas dapat dilihat pada Tabel 2.

\section{Tabel 1}

Hasil Uji Multikolinearitas

\begin{tabular}{|c|c|c|}
\hline \multicolumn{3}{|c|}{ Hasil Uji Multikolinearitas } \\
\hline Variabel & VIF & Keterangan \\
\hline X. 1 & 1,158 & Non Multiko \\
\hline X.2 & 1,121 & Non Multiko \\
\hline X.3 & 1,209 & Non Multiko \\
\hline$X .4$ & 1,117 & Non Multiko \\
\hline$X .5$ & 1,152 & Non Multiko \\
\hline X.6 & 1,114 & Non Multiko \\
\hline$X .7$ & 1,042 & Non Multiko \\
\hline
\end{tabular}

Sumber: Data Primer Diolah

Hasil perhitungan nilai seperti pada Tabel 2 menunjukkan bahwa kesemua variabel yang diuji yaitu 7 variabel yang terdiri dari X1, X.2, X.3, X.4, X.5, X.6, X.7, tidak memiliki nilai VIF di atas 4. Hasil ini mengandung makna bahwa variabel tersebut tidak terjadi multikolinearitas. Untuk mengetahui ada tidaknya gejala heteroskerjastisitas, maka dalam penelitian ini untuk persamaan regresi 
dilakukan uji t. Hasil uji t tersebut apabila nilai $t>0,05$ tidak signifikan, artinya tidak terjadi heterokedastisitas, apabila nilai $\mathrm{t}<0,05$ signifikan, artinya terjadi heterokedastisitas. Pengujian data berdasarkan uji t dapat dilihat pada Tabel 3.

Tabel 2

Hasil Uji Heterokedastisitas

\begin{tabular}{|c|c|c|}
\hline Variabel & $\mathbf{t}$ & Keterangan \\
\hline X.1 & 13,450 & Non Hetero \\
X.2 & 23,377 & Non Hetero \\
X.3 & 24,665 & Non Hetero \\
X.4 & 16,814 & Non Hetero \\
X.5 & 22,697 & Non Hetero \\
X.6 & 21,674 & Non Hetero \\
X.7 & 26,769 & Non Hetero \\
\hline
\end{tabular}

Sumber: Data Primer Diolah

Berdasarkan hasil uji t tersebut, di mana perolehan angka uji t dari ketujuh variabel tersebut tidak diperoleh angka yang lebih kecil dari 0,05, artinya tidak terdapat gejala heteroskerjastisitas. Hasil perhitungan Durbin Watson tes dari 7 variabel yang dianalisis menunjukkan hasil perolehan angka sebesar 2,03 8, berdasarkan pada pendapat dari Gujarati (1985), hasilnya adalah sebagai berikut:

- Nilai Durbin Watson sebesar 2,038, dengan $\mathrm{n}=80$ dan $\mathrm{k}$ (variabel bebas) $=7$, dengan signifikansi sebesar $5 \%$ maka ditemukan $\mathrm{d}_{\mathrm{u}}=1,71$ dan $\mathrm{d}_{\mathrm{N}}=1.47$.

- Berdasarkan hasil tersebut maka besarnya, Durbin Watson test sebesar 2,038 terletak pada:

$\mathrm{d}_{\mathrm{u}}<$ D.W $<4-\mathrm{d}_{\mathrm{u}}$ maka $1,71<2,119<(4-1,171)=1,71<2,038<2,29$

Hasil ini menunjukkan menerima null hipotesis, artinya bahwa model regresil tidak mengandung korelasi serial atau autokorelasi.

Model regresi yang baik adalah distribusi data normal atau mendekati normal. Pengambilan keputusan untuk mengetahui adanya normalitas atau tidak dapat ditentukan dengan kriteria sebagai berikut (Santoso, 2001): (a) Jika data menyebar di sekitar garis diagonal dan mengikuti arah garis diagonal, maka model regresi memenuhi asumsi normalitas. (b) Jika data menyebar jauh dari garis 
diagonal dan/atau tidak mengikuti arah garis diagonal, maka model regresi tidak memenuhi asumsi normalitas.

Hasil pengujian menunjukkan signifikansi F sebesar 0,073 lebih kecil dari 0,1 atau $10 \%$. Hasil ini menunjukkan bahwa Etos Kerja $\left(\mathrm{X}_{1}\right)$, Semangat untuk bersaing $\left(\mathrm{X}_{2}\right)$, Kompetensi berbisnis $\left(\mathrm{X}_{3}\right)$, Gaya kepemimpinan $\left(\mathrm{X}_{4}\right)$, Kemampuan melihat peluang bisnis $\left(\mathrm{X}_{5}\right)$, Kemampuan manajerial $\left(\mathrm{X}_{6}\right)$, dan Kekuatan utama yang menonjol $\left(\mathrm{X}_{7}\right)$ secara bersama-sama berpengaruh signifikan terhadap Kesuksesan bisnis (Y).

\section{Tabel 3}

Hasil Statistik Regresi Berganda

\begin{tabular}{|c|c|c|c|c|}
\hline $\begin{array}{c}\text { Variabel } \\
\text { Bebas }\end{array}$ & $\beta$ & Beta & $\mathbf{t}$ & Sig. t \\
\hline Konstanta & 0.664 & & 0.405 & Tidak signifikan \\
$\mathrm{X}_{1}$ & -0.032 & -0.022 & 0.851 & Tidak signifikan \\
$\mathrm{X}_{2}$ & 0.338 & 0.308 & 0.011 & Signifikan \\
$\mathrm{X}_{3}$ & -0.184 & -0.168 & 0.172 & Tidak signifikan \\
$\mathrm{X}_{4}$ & -0.022 & 0.021 & 0.856 & Tidak signifikan \\
$\mathrm{X}_{5}$ & 0.229 & 0.240 & 0.047 & Signifikan \\
$\mathrm{X}_{6}$ & -0.066 & -0.066 & 0.572 & Tidak signifikan \\
$\mathrm{X}_{7}$ & 0.168 & 0.140 & 0.219 & Tidak signifikan \\
\hline $\begin{array}{l}\mathrm{T}_{\text {tabel }} \\
\text { Multiple R }\end{array}$ & $=1,2925$ & & \\
$\mathrm{R}$ Square & $=0,410$ & & \\
Adjusted R Square & $=0,168$ & & \\
F $_{\text {hitung }}$ & $=1,964$ & & \\
Signifikan F & $=0,000$ &
\end{tabular}

Sumber: Data Diolah

Besarnya adjusted $R$ square adalah 0,168 atau 16,8\%, artinya Etos kerja $\left(\mathrm{X}_{1}\right)$, Semangat untuk bersaing $\left(\mathrm{X}_{2}\right)$, Kompetensi berbisnis $\left(\mathrm{X}_{3}\right)$, Gaya kepemimpinan $\left(\mathrm{X}_{4}\right)$, Kemampuan melihat peluang bisnis $\left(\mathrm{X}_{5}\right)$, Kemampuan manajerial $\left(\mathrm{X}_{6}\right)$, dan Kekuatan utama yang menonjol terhadap Kesuksesan bisnis (Y) sebesar 16,8\%, sedangkan sisanya yaitu sebesar 83,2\% dipepgaruhi oleh variabel lain diluar 7 variabel tersebut. Pengaruh secara parsial masing-masing 
variabel bebas terhadap variabel terikat diketahui dari signifikansi $\mathrm{t}, \mathrm{t}<10 \%$ maka variabel bebas yang diuji tersebut secara parsial berpengaruh signifikan terhadap varlabel terikat pada tingkat signifikansi $10 \%$. Berdasar pada hasil perhitungan secara statistik (Tabel 3), maka dapat dijelaskan sebagai berikut.

Perolehan angka konstanta sebesar 0,664 bertanda positif, artinya tanpa adanya perubahan dari variabel bebas maka akan terjadi perubahan kesuksesan bisnis sebesar 0,664, artinya angka konstanta tersebut tidak berpengaruh besar terhadap kesuksesan bisnis. Sedangkan perolehan angka Sig.t untuk konstanta sebesar 0,405 lebih besar dari 0,1. Hasil ini menunjukkan bahwa perolehan angka konstanta tersebut tidak berpengaruh secara signifikan terhadap Kesuksesan Bisnis. Perolehan angka $\beta$ (Beta) pada variabel Etos Kerja $\left(X_{1}\right)$ sebesar -0,032, artinya dengan semakin menurunnya etos kerja dari wirausaha menyebabkan peningkatan kesuksesan bisnis. Perolehan angka negatif ini menunjukkan adanya hasil yang berlawanan, di mana kesuksesan bisnis yang seharusnya dipengaruhi oleh etos kerja, dalam hal ini peningkatan etos kerja akan berpengaruh terhadap penurunan kesuksesan bisnis. Hasil ini disebabkan karena semangat kerja dari seseorang dalam mengawali suatu bisnis dan setelahnya ada suatu perbedaan. Pada awal dimulainya bisnis semangat kerja seorang sangat tinggi agar dapat memperoleh kesuksesan. Pada masa di mana bisnis tersebut telah dijalankan dan sudah memperoleh suatu kesuksesan maka semangat yang timbul dari seorang wirausaha mengalami kemunduran. Perolehan angka Sig.t untuk variabel Etos Kerja $\left(\mathrm{X}_{1}\right)$ sebesar 0,851 lebih besar dari 0,1, artinya variabel Etos Kerja $\left(\mathrm{X}_{1}\right)$ tidak berpengaruh secara signifikan terhadap Kesuksesan Bisnis.

Perolehan angka $\beta$ (Beta) pada variabel semangat untuk bersaing $\left(\mathrm{X}_{2}\right)$ sebesar 0,338 , perolehan $\beta$ variabel ini dengan tanda positif menunjukkan bahwa dengan bertambahnya semangat untuk bersaing dari wirausaha akan dapat meningkatkan kesuksesan bisnisnya. Keadaan ini mengindikasikan bahwa semangat bersaing wirausaha memiliki peran yang penting, di mana dengan adanya semangat untuk bersaing ini membuat mereka berbisnis untuk memperbaiki kinerja pelayanan dan pengembangan yang dilakukan agar dapat meningkatkan kesuksesan bisnisnya. Perolehan angka Sig.t untuk variabel semangat untuk Bersaing $\left(\mathrm{X}_{2}\right)$ sebesar 0,011 lebih kecil dari 0,1, artinya variabel 
Semangat untuk Bersaing $\left(\mathrm{X}_{2}\right)$ berpengaruh secara, signifikan terhadap Kesuksesan Bisnis. Hasil ini menunjukkan bahwa dengan meningkatnya kemampan semangat bersaing, bagi para pengbisnis akan meningkatkan kesuksesan bisnis yang mereka tekuni.

Perolehan angka $\beta$ (Beta) sebesar -0,184 untuk variabel Kompetensi Berbisnis $\left(\mathrm{X}_{3}\right)$, tanda negatif disini mengandung makna adanya arti yang berlawanan, di mana dengan Kompetensi Berbisnis yang semakin meningkat akan dapat menurunkan kesuksesan berbisnis, sedangkan penurunan Kompetensi Berbisnis akan meningkatkan kesuksesan bisnis. Kondisi ini terjadi disebabkan adanya pengalaman bisnis yang semakin lama dan kesuksesan bisnis yang semakin meningkat membuat mereka kurang optimal dalam mengimplementasikaan keterampilan yang dimiliki dalam menjalankan bisnis. Pekerjaan-pekerjaan yang telah biasa dilakukan sebelumnya dan adanya tingkat kesulitan tertentu, dengan pengalaman yang dimiliki membuat mereka tidak lagi banyak hambatan dan masalah dalam menjalankan bisnisnya. Berdasar pada penjelasan tersebut menunjukkan bahwa wirausaha yang telah berhasil dalam menjalankan bisnisnya kurang memiliki tantangan yang berarti dalam menjalankan bisnisnya, sehingga membuat mereka beranggapan bahwa kesuksesan bisnisnya dikarenakan semakin berkurangnya pekerjaan yang berat dan berkurangnya pekerjaan yang membutuhkan keterampilan yang tinggi. Perolehan Sig.t untuk variabel Kompetensi-Berbisnis $\left(\mathrm{X}_{3}\right)$ sebesar 0,172, lebih besar dari 0, 1, artinya variabel Kompetensi Berbisnis $\left(\mathrm{X}_{3}\right)$ tidak berpengaruh secara signifikan terhadap Kesuksesan Bisnis.

Perolehan angka $\beta$ (Beta) sebesar $-0,022$ pada variabel Gaya Kepemimpinan $\left(\mathrm{X}_{4}\right)$, tanda negatif hasil ini menunjukkan adanya makna yang berbalik, di mana gaya kepemimpinan yang berkembang akan menyebabkan penurunan kesuksesan bisnis, sedangkan gaya kepemimpinan yang tidak dikembangkan akan menambah kesuksesan bisnis. Keadaan ini diakibatkan karena responden dalam penelitian ini adalah perbisnisan kecil dan jenis bisnis jasa, di mana tidak memerlukan banyak karyawan. Jumlah karyawan yang kecil tersebut, mengakibatkan kemampuan kepemimpinan tidak banyak diperlukan dalam membangun bisnisnya. Dalam, variabel ini responden beranggapan bahwa 
gaya kepemimpinan bukan merupakan kebutuhan yang mendesak untuk diimplementasikan guna mendukung kesuksesan bisnis merekan. Perolehan Sig.t untuk variabel Gaya Kepemimpinan $\left(\mathrm{X}_{4}\right)$ sebesar 0,856 lebih besar dari 0,1, artinya variabel Gaya Kepemimpinan $\left(\mathrm{X}_{4}\right)$ tidak berpengaruh secara. signifikan terhadap Kesuksesan Bisnis.

Perolehan angka $\beta$ (Beta) variabel kemampuan melihat peluang bisnis $\left(\mathrm{X}_{5}\right)$ sebesar 0,229, artinya dengan peningkatan kemampuan melihat peluang bisnis dari para wirausaha akan dapat meningkatkan kesuksesan bisnis. Kemampuan ini dianggap menjadi prioritas dari wirausaha yang menjadi responden dalam penelitian ini. Hal tersebut disebabkan dengan berjalannya bisnis yang telah dilakukan selama ini, di mana agar dapat mermpertahankan dan meningkatkan kinerjanya harus dilakukan dengan selalu berbisnis untuk mengikuti perkembangan-perkembangan bisnis yang terjadi. Bisnis untuk selalu melihat dan mengamati perkembangan bisnis yang selalu terjadi ini merupakan prioritas utama yang dapat mendukung kesuksesan bisnisnya. Perolehan angka Sig.t untuk variabel Kemampuan Melihat Peluang Bisnis $\left(\mathrm{X}_{5}\right)$ sebesar 0,047 lebih kecil dari 0,1 , artinya variabel Kemampuan Melihat Peluang Bisnis $\left(\mathrm{X}_{5}\right)$ berpengaruh secara signifikan terhadap Kesuksesan Bisnis.

Perolehan angka $\beta$ (Beta) variabel Kemampuan Manajerial sebesar -0,066, tanda negatif dari hasil ini menunjukkan makna yang berlawanan, di mana peningkatan kemampuan manajerial akan dapat menurunkan kesuksesan bisnis, begitu pula sebaliknya. Keadaan ini disebabkan dari responden penelitiannya, yaitu wirausaha dengan skala yang kecil dan jenis bisnis, terbatasnya skala bisnis dan jenis bisnis jasa yang menjadi objek penelitian ini berdampak kecilnya jumlah karyawan yang dimiliki. Di samping itu, jumlah karyawan yang kecil tersebut, membuat responden beranggapan bahwa upaya manajerial tidak banyak diperlukan oleh mereka dalam mengelola bisnisnya. Tanggapan responden terhadap kemampuan manajerial yang dianggap kurang penting tersebut secara langsung berpengaruh terhadap jawaban kesuksesan bisnisnya. Kesuksesan bisnis yang selama ini diperoleha mereka tidak dipengaruhi oleh kemampuan manajerial yang dilakukan. Pada kondisi ini pekerjaan-pekerjaan yang bersifat praktis dan mendukung pemecahan masalah yang dihadapi lebih sering mereka gunakan. 
Perolehan Sig.t. untuk variabel Kemampuan Manajerial $\left(\mathrm{X}_{6}\right)$ sebesar 0,572 lebih besar dari 0,1, artinya variabel Kemampuan Manajerial $\left(\mathrm{X}_{6}\right)$ tidak berpengaruh secara. signifikan terhadap Kesuksesan Bisnis.

Perolehan angka $\beta$ (Beta) variabel Kekuatan Utama yang Menonjol sebesar 0, 167, artinya dengan meningkatnya Kekuatan Utama yang Menonjol akan meningkatkan kesuksesan bisnis. Kekuatan Utama yang Menonjol. Ini meliputi ambisi, dan kemauan dari diri sendiri untuk berbisnis memiliki peran yang mereka anggap penting untuk mendukung kesuksesan bisnis mereka selama ini. Perolehan Sig.t untuk variabel Kekuatan Utama yang Menonjol $\left(\mathrm{X}_{8}\right)$ sebesar 0,219 lebih besar dari 0,1, artinya variabel Kekuatan Utama yang Menonjol $\left(\mathrm{X}_{8}\right)$ tidak berpengaruh secara signifikan terhadap Kesuksesan Bisnis.

\section{Pengujian Hipotesis}

Hipotesis yang diajukan dalam penelitian terdiri dari 2 hipotesis: (1) Diduga terdapat pengaruh yang signifikan dari variabel karakteristik wirausaha secara simultan terhadap kesuksesan bisnis. (2) Diduga terdapat pengaruh yang signifikan dari variabel karakteristik wirausaha secara parsial terhadap kesuksesan bisnis. Berdasarkan hasil penelitian menunjukkan ketujuh variabel yang terdiri dari Etos Kerja, Semangat Untuk Bersaing, Kompetensi Berbisnis, Gaya Kepemimpinan, Kemampuan Melihat Peluang Bisnis, Kemampuan Manajerial, dan Kekuatan Utama yang Menonjol mempunyai pengaruh dan signifikan terhadap Kesuksesan Bisnis, dengan demikian maka Hipotesis pertama diterima. Artinya, semua variabel yang terdiri dari Etos Kerja, Semangat Untuk Bersaing, Kompetensi Berbisnis, Gaya Kepemimpinan, Kemampuan Melihat Peluang Bisnis, Kemampuan Manajerial, dan Kekuatan Utama yang Menonjol secara bersama-sama berpengaruh secara signifikan terhadap Kesuksesan Bisnis.

Pengaruh secara parsial variabel dari Etos Kerja, Semangat Untuk Bersaing, Kompetensi Berbisnis, Gaya Kepemimpinan, Kemampuan Melihat Peluang Bisnis, Kemampuan Manajerial, dan Kekuatan Utama yang Menonjol terhadap kesuksesan bisnis, hasilnya hanya 2 variabel yang secara signifikan berpengaruh secara parsial. Variabel yang berpengaruh tersebut meliputi variabel semangat untuk bersaing dan kemampuan melihat peluang bisnis. Sedangkan lima 
variabel yang lain terdiri dari etos kerja, kompetensi berbisnis, gaya kepemimpinan, kemampuan manajerial dan kekuatan utama yang menonjol tidak berpengaruh secara signifikan terhadap kesuksesan bisnis. Hasil ini menunjukkan bahwa tidak semua variabel hipotesisnya diterima, dan hanya dua variabel yang hipotesisnya diterima yaitu variabel semangat untuk bersaing dan kemampuan melihat peluang.

\section{PEMBAHASAN}

Kesuksesan bisnis merupakan ukuran dari kesuksesan seseorang dalam menjalankan bisnisnya. Kesuksesan bisnis di sini indikator yang digunakan adalah peningkatan penjualan, peningkatan jumlah pelanggan, meningkatnya aset dan meningkatnya keuntungan yang diperoleh. Dalam penelitian ini, peneliti melakukan kajian sampai seberapa besar kesuksesan bisnis dipengaruhi oteh karakteristik wirausaha yang terdiri dari Etos Kerja, Semangat Untuk Bersaing, Kompetensi Berbisnis, Gaya Kepemimpinan, Kemampuan Melihat Peluang Bisnis, Kemampuan Manajerial, dan Kekuatan Utama yang Menonjol.

Karakteristik yang berkenaan dengan Etos Kerja di sini dimaksudkan adalah bagaimana seorang pengbisnis mencintai dan melaksanakan pekerjaan atau tugas yang menjadi tanggung jawabnya dilaksanakan dengan dedikasi yang tinggi. Perolehan $\beta$ (Beta) dari variabel Etos Kerja yang negatif menunjukkan adanya hasil yang berlawanan, di mana peningkatan etos kerja dari wirausaha akan berdampak pada penurunan kesuksesan bisnis. Hasil yang berlawanan tersebut disebabkan oleh beberapa hal, yaitu: (1) Responden dalam penelitian ini sudah memiliki pengalaman dalam berbisnis; (2) Responden dalam penelitian merasa bahwa selama menjalankan bisnisnya ada suatu kesuksesan yang telah diperoleh. Kesuksesan yang telah diperoleh wirausaha tersebut membuat mereka memiliki persepsi bahwa tidak lagi diperlukan kerja keras yang berlebihan untuk mengejar kesuksesan yang lebih tinggi. Mereka lebih banyak menikmati atas kesuksesan yang mereka peroleh selama ini, sehingga upaya kerja keras sebagaimana mereka pada waktu merintis bisnisnya sudah tidak lagi merupakan kebutuhan bagi mereka. Secara total perolehan nilai rata-rata jawaban pertanyaan responden sebesar 1,58, yaitu berada pada posisi antara sangat setuju dan setuju. Keadaan ini 
menunjukkan bahwa persepsi responden terhadap pemyataan bahwa etos kerja dibutuhkan oleh seorang pengbisnis dalam menjalankan bisnisnya.

Variabel semangat untuk bersaing merupakan karakteristik wirausaha yang berkenaan dengan kemampuan yang dimiliki oleh seseorang untuk menguasai pasar dengan menggunakan strategi tertentu. Hasil penelitian ini menunjukkan adanya pengaruh yang signifikan variabel semangat untuk bersaing terhadap kesuksesan bisnis. Hasil ini diperkuat dengan perolehan nilai rata-rata dari jawaban responden terhadap butir-butir yang ditanyakan. Perolehan angka sebesar 1,855 menunjukkan bahwa perolehan angka tersebut menunjukkan bahwa responden setuju bahwa semangat untuk bersaing diperlukan oleh seorang pengbisnis untuk mendapatkan kesuksesan dalam bisnisnya.

Semangat bersaing yang dimaksudkan dalam meliputi: (1) kepuasan seorang pen.gbisnis memiliki kepuasan apabila mereka berhasil mengerjakan pekerjaan dengan cara yang lebih baik; (2) bagian dari kepuasan adalah kemampuannya memenangkan persaingan; (3) menemukan suatu kepuasan dalam bekerja yang penuh tantangan; (4) bersedia berkorban guna memperoleh kemungkinan imbalan yang lebih besar. Berdasar pada pernyataan tersebut maka agar dapat menjadi seorang wirausaha yang memiliki semangat bersaing maka pembinaa karakteristik yang dapat mendorong beberapa kepuasan yang berkenaan dengan semangat bersaing tersebut hendaknya selalu dibina dan dibisniska agar selalu terasah dengan baik.

Kompetensi berbisnis merupakan keterampilan khusus yang dimiliki yang berguna dalam membantu bisnis menjadi berkembang, Variabel ini berdasarkar hasil analisis bertanda negatif, di mana peningkatan kompetensi berbisnis yang dilakukan oleh wirausaha menurunkan kesuksesan bisnis. Seperti halnya pada variabel etos kerja, di mana indikasi kompetensi berbisnis terdiri dari keterampilan tinggi, kemampuan menyelesaikan tugas yang sulit merupakan kebutuhan mereka pada awal-awal memulai bisnisnya. Di mana pada awal dimulainya bisnis mereka belum banyak memiliki pengalaman dan memerlukan banyak waktu dan tenaga untuk dapat menyelesaikan hambatan dan masalah yang dihadapi. Pada saat di mana para wirausaha telah memiliki banyak pengalaman dan kesuksesan bisnisnya telah dapat dilihat dan din ikmati maka kompetensi 
berbisnis ini inenjadi menurun. Pengalaman yang dimiliki dalam menyelesaikan masalah dan hambatan akan membuat mereka telah terbiasa, sehingga, dalam kondisi saat ini mereka tidak lagi merasa bekerja dengan tingkat keterampilan yang tinggi dan adanya hambatan dalam menjalan bisnisnya.

Meskipun demikian dalam menjalankan bisnisnya berdasar pada pengamatan orang lain, mereka bekerja dengan keterampilan tinggi dan mengerjakan tugas-tugas yang sulit untuk dilakukan oleh banyak orang. Tanggapan responden terhadap butir-butir pertanyaan menunjukkan perolehan angka rata-rata sebesar 2,44. Hasil ini menunjukkan bahwa perolehan angka tersebut lebih mendekati pada posisi dimana responden tidak banyak mendukung bahwa kesuksesan bisnis dipengaruhi oleh kompetensi berbisnis. Dalam hal ini responden merasa bahwa kompetensi bisnis bukan merupakan karakteristik yang utama agar dapat mencapai suatu kesuksesan bisnis.

Gaya kepemimpinan merupakan suatu pendekatan yang digunakan untuk memotivasi dan mengarahkan orang lain supaya mereka memberikan kinerja yang baik. Variabel gaya kepemimpinan ini berdasarkan analisis yang telah dilakukan tidak berpengaruh secara signifikan terhadap kesuksesan bisnis. Berdasarkan deskripsi butir-butir pertanyaan pada variabel gaya kepemimpinan menunjukkan bahwa jawaban responden secara rata-rata perolehan angkanya sebesar 2,33. Posisi perolehan angka sebesar 2,33 menunjukkan bahwa gaya kepemimpinan bukan merupakan karakteristik yang paling utama dalam mendukung seseorang dalam menjalankan bisnisnya. Perolehan angka negatif menunjukkan adanya anggapan yang berlawanan, di mana kesuksesan bisnis tidak dipengaruhi oleh gaya kepemimpinan begitu pula sebaliknya. Keadaan ini dapat dilihat pada jenis dan skala bisnis yang dimiliki oleh responden tidak banyak memerlukan karyawan dalam jumlah yang besar. Jumlah karyawan yang tidak banyak tersebut menjadikan kurangnya kemampuan kepemimpinan yang dimiliki oleh seseorang dalam menjalankan bisnisnya. Kemampuan kepemimpinan baru dapat manfaatkan secara optimal pada kegiatan yang hinvak melibatkan sumber daya manusia. Berdasar pada keadaan tersebut maka hasil penelitian ini sebenarnya sesuai dengan situasi dan kondisi yang dimiliki oleh responden yaitu pengbisnis yang bergerak di bidang jasa, di mana jumlah karyawannya kecil dan tidak diperlukan 
kemampuan kepemimpinan yang andal dalam mendukung operasional bisnisnya agar mencapai kesuksesan bisnis.

Kemampuan melihat peluang bisnis merupakan upaya para wirausaha untuk menyesuaikan produk yang dihasilkan dengan perbisnisan pasar yang terjadi. Variabel kemampuan melihat peluang bisnis berdasarkan analisis regresi menunjukkan adanya pengaruh yang signifikan terhadap kesuksesan bisnis. Berdasar pada hasil deskripsi pernyataan responden terhadap pertanyaan yang diberikan, di mana secara rata-rata perolehan angkanya sebesar 2,44. Hasil dari analisis menunjukkan bahwa kemampuan melihat peluang bisnis berpengaruh terhadap kesuksesan bisnis. Kemampuan ini dianggap, menjadi prioritas dari wirausaha yang menjadi responden dalam penelitian ini. Hal tersebut disebabkan dengan berjalannya bisnis yang telah dilakukan selama ini, di mana agar dapat mermpertahankan dan meningkatkan kinerjanya harus dilakukan dengan selalu berbisnis untuk mengikuti perkembangan-perkembangan bisnis yang terjadi. Bisnis untuk seIalu melihat dan mengamati perkembangan bisnis yang selalu terjadi ini merupakan prioritas utama yang dapat mendukung kesuksesan bisnisnya.

Kemampuan manajerial merupakan suatu kemampuan seseorang yang hendaknya dimiliki guna mendukung mereka dalam menjalankan bisnisnya dengan menggunakan pendekatan manajemen modern. Variabel ini setelah dilakukan analisis regresi tidak berpengaruh terhadap kesuksesan bisnis. Perolehan angka rata-rata dari jawaban responden yang berkenaan dengan variabel kemampuan manajerial sebesar 2,28. Hasil ini menunjukkan bahwa kemampuan manajerial bukan merupakan kebutuhan karakteristik yang utama yang dimiliki seseorang dalam berwirausaha. Hasil ini juga dapat dilihat dari perolehan $\beta$ (Beta) yang negatif, di mana kemampuan manajerial wirausaha tidak berpengaruh terhadap kesuksesan bisnis. Keadaan ini diperkuat dengan sedikitnya jumlah karyawan yang dimiliki oleh responden. Jumlah orang yang terbatas, maka kegiatan manajerial kurang dapat digunakan secara maksimal, hal ini berkenaan dengan arti manajemen itu sendiri yang lebih mengutamakan kerjasama antar individu guna mencapai suatu tujuan. Di samping itu jenis bisnis jasa yang 
ditekuni oleh responden kurang memiliki kebutuhan yang tinggi terhadap kemampuan manajerial yang harus dimiliki oleh seseorang dalam berwirausaha.

\section{KESIMPULAN}

Kekuatan utama yang menonjol merupakan kemampuan yang dimiliki oleh seseorang yang meliputi ketekiman, kedisiplinan, dan bekerja secara terinci diperlukan guna menjadi wimbisnis yang berhasil. Variabel ini berdasarkan hasil analisis regresi menunjukkan tidak adanya pengaruh yang signifikan terhadap kesuksesan. Hasil dari deskripsi variabel menunjukkan perolehan angka rata-rata sebesar 2,11, artinya variabel kekuatan utama yang menonjol ini bukan merupakan karakteristik utama yang diperlukan oleh seorang wirausaha dalam menjalankan bisnisnya. Hasil apabila dililhat dari perolehan (Beta) bertanda negatif, menandakan bahwa kesuksesan bisnis tidak dipengruhi oleh kekuatan utama yang menonjol yang dimiliki oleh wirausaha. Kekuatan yang menonjol ini terdiri dari ambisi, kerja berdasarkan intuisi. Perolehan hasil yang berlawanan tersebut dapat disebabkan oleh pengalaman berbisnis dari responden, dan kesuksesannya. Keadaan yang telah dirasakan oleh wirausaha. yang berhasil dan memiliki pengalaman yang memadai telah menyebabkan berkurangnya ambisi dan penggunaan intuisi dalam menjalankan bisnisnya. Mereka lebih cenderung hanya mengikuti saja perkembangan bisnis yang ada tanpa banyak berkeinginan untuk membangun bisnisnya berkembang cepat dan lebih besar dan kurun waktu yang pendek. Di samping itu mereka juga tidak lagi menggunakan intuisi mereka dalam. mengembangkan bisnisnya, karena mereka lebih mengarah pada penikmatan hasil bisnis yang telah mereka jalankan selama ini dengan kesuksesannya. 


\section{DAFTAR PUSTAKA}

Ananto, B. 2000. Studi Karakteristik Kewirausahaan Mahasiswa Fakultas Ekonomi Universitas Brawijaya, Laporan Penelitian Yang Tidak Dipublikasikan. Malang: Fakultas Ekonomi Universitas Brawijaya.

Babbie, E. 1992. The Practice of Social Research, Sixth Edition, Wadwoth Publishing Company California, USA.

Casson, M. 1982, The Entrepreneur: an Economic Theory, Martin Robertson, Oxford USA.

Chell, E., Haworrth, L, and Breasly, S. 1991. The Entrepreneurial Personality, First Edition, Routledge, London.

Davis, D., and Cosenza, R.M. 1993. Business Research for Decision Making, Third Editian, Wadsworth Publishing Company Belmont, California, USA.

Gartner, W. 1985. a Framework for describing the Phenomenon of New Venture Creation, Academy of Management Review, Vol 10, pp 696-706

Gillad, B., and Le vine, P. 1986. a Behavioral Model of Entrepreneurial Supply, Journal of Small Business Management, Vol 24, pp 45-5 1.

Gujarati, D. 1995. Basic Econometrics, Third Edition, McGraw-Hill International Editions, Economic Series, Singapore.

Hawkins, K.L., and Turla, P.A. 1986. Test Yours Entrepreneurial IQ, Barkley Book, USA.

Hair, LE, Anderson, R.E., Tatham, R.L., and Black, W.C., 1992, Multivariate Data Analysis With Readings, Third Edition, MacMillan Publishing Company, New York, USA.

Low. M.B., and MacMillan. I.C. 1988. Entrepreneurship: Past research and Future Challenges. Journal of Management, Vol. 14, pp. 136-61.

Littunen, H. 2000. Entrepreneurship and the Characteristics of The Entrepeneurial Personality, International Journal of Entrepreneurial Behaviour and Research, Vol 6 No. 6, pp. 295-309.

Mc Cleland, D.C. 1965, Achievment and Entrepreneurship a Longitudinal Study, Journal of Personality and Social Psychology, Vol 1, No 4, pp 386-392.

Musselman, VA., and Jackson, J.H. 1984. Introduction to Modem Business, Prentice Hall, Inc., USA-

Meredith G.G. et al. 1995. Kewirausahaan Teori dan Praktek, Terjemahan. Jakarta: Pustaka Binaman Pressindo. 
Peggy, L A, and Kuehl, C.R. 2003. Entrepreneuship, Third Edition, Prentice Hall, New Jersey. USA.

Rotter. LB. 1975. Some Problems and Misconception Realted to The Construct of Internal Versus Exteinal Control of Reinforcement. Journal of Consulting and Clinical Psdychology, Vol 43, pp 56-57.

Rotter, J.B. 1990. Internal Versus External of Reinforcement, American Psychologist, Vol. 45, pp. 489-493.

Singarimbun, M. dan Sofian, E. 1995. Metode Penelitian Survei. Edisi Revisi, Jakarta: Penerbit LP3ES.

Steade, R.D, Lowry, J.R., Glos, R.E. 1998. Business, Its Nature and Environment, South-Western Publishing CO, West Chicago, USA.

Santoso, S. 2001. Buku Latihan SPSS Statistik Parametrik. Jakarta: PT. Elex Media Komputindo.

Suharsimi, A. 2002. Prosedur Penelitian Suatu Pendekatan Praktek. Edisi Revisi V. Jakarta: Penerbit Rineka Cipta. 